\title{
Effects of Olea europaea L. Leaf Metabolites on the Tilapia (Oreochromis niloticus) and Three Stored Pests, Sitophilus granarius, Tribolium confusum and Acanthoscelides obtectus
}

\author{
Ahmet Kısa $^{\oplus 1}$, Mehmet Akyüz ${ }^{\oplus 1}$, Hikmet Yeter Çoğun ${ }^{\oplus 2}$, Şaban Kordali ${ }^{\oplus 3}$ \\ Ayşe Usanmaz Bozhüyük ${ }^{\oplus 4}$, Binnur Tezel ${ }^{\oplus 1}$, Umran Şiltelioğlu ${ }^{\oplus 1}$, \\ Barış Anıl $^{\oplus 5}$ and Ahmet Çakır ${ }^{\oplus 1^{*}}$ \\ ${ }^{1}$ Kilis 7 Aralık University, Faculty of Science and Arts, Department of Chemistry,79000-Kilis, \\ Türkiye \\ ${ }^{2}$ Çukurova University, Ceyhan Veterinary Faculty, Department of Basic Sciences, Ceyhan, \\ Adana, Türkiye \\ ${ }^{3}$ Atatürk Üniversity, Faculty of Agriculture, Department of Plant Protection, 25240-Erzurum, \\ Türkiye \\ ${ }^{4}$ Iğdır University, Faculty of Agriculture, Department of Plant Protection, 76000-I $\breve{g} d ı$, \\ Türkiye \\ ${ }^{5}$ Atatürk University, Faculty of Science, Department of Chemistry, 25240-Erzurum, Türkiye
}

(Received July 17, 2017; Revised September 14,2017; Accepted September 15,2017)

\begin{abstract}
Olea europea L. emerged as a good source of traditional medicine for the treatment of various ailments of various countries of the world, in particular Mediterranean countries. In this study, oleuropein (1), oleanolic acid (2), maslinic acid (3), a mixture of erythrodiol and uvaol (4 and 5) isolated from the leaves of olive were added at two concentrations $(1 \mathrm{~g} / 100 \mathrm{~g}$ feed and $4 \mathrm{~g} / 100 \mathrm{~g}$ feed) into fish feed. Oreochromis niloticus (Nile tilapia) were fed twice a day with the feed during 96 hours. The levels of alanine aminotransferase (ALT), aspartate aminotransferase (AST), alkaline phosphatase (ALP) enzymes and glucose levels in the serums of fishes fed with pure compounds were found to be higher as compared with the control group. Pure metabolites affect the liver metabolism of Nile tilapia. These results suggested that the compounds tested affect the liver metabolism of Nile tilapia. Compounds 1, 2, 3 and $\mathbf{4}+\mathbf{5}(2.5,5.0$ and 7.5 mg/Petri dish concentrations) were also tested for contact toxic effects against three important stored pests, Sitophilus granarius (weevil), Tribolium confusum (confused flour beetle) and Acanthoscelides obtectus (bean weevil). The toxic effects of the metabolites were lower than those of the insecticide, dichlorvos (DDVP). DDVP caused complete mortality of the insects after 48 hours of treatments, the metabolites caused the mortality rates 16.7-63.3\%, 13.3-67.0\% and 26.7-59.0\% of $S$. granarius, T. confusum and A. obtectus, respectively. Maslinic acid (3) has the most toxic compound with the lowest $\mathrm{LC}_{50}$ values $(0.66 \mathrm{mg} /$ Petri, $0.61 \mathrm{mg} /$ Petri and $1.71 \mathrm{mg} /$ Petri for S. granarius, T. confusum and A. obtectus, respectively). These results show that maslinic acid (3) as well as other substances can be used as natural insecticides against these pests.
\end{abstract}

Keywords: Olea europea; oleuropein; maslinic acid; Oreochromis niloticus; storage pest. (C) 2018 ACG Publications. All rights reserved.

* Corresponding author: E Mail: acakir@kilis.edu.tr Phone: +90 348 8222350; Fax: + 903488222351 


\section{Introduction}

It is well known that the majority of the synthetic drugs used in the treatment of various diseases in medicine have undesirable side effects. Hence, the scientist has been focused on alternative natural drugs from medicinal plants and other organisms. Environmental pollutants, synthetic chemicals, radiations a result of the industrial and technological development cause many diseases in humans and other living organisms. The fishes living aquatic ecosystems are also affected by the environmental factors. Recently, natural agents have been considered as alternatives to reduce the harmful effects of synthetic reagents to the environment. Natural reagents give rise to lower risk for the environment due to their rapid biodegradation than those of synthetic chemicals. Pharmaceutical drugs can also be obtained from the herbal drugs with the low cost, for this reason recent studies have focused on medicinal plants and their metabolites used in the treatment of humans and other living organisms [1$6]$.

Insect pest cause extensive damage to stored grains and their products and it leads to loss of 5$10 \%$ in the temperate zone and $20-30 \%$ in the tropical zone of stored grains and their products $[7,8]$. Wheat weevil (Sitophilus granarius; Coleoptera), known also as grain weevil cause significant damage to harvested stored products including wheat, oats, rye, rice and corn. This pest causes significant damage to harvested stored products. The confused flour beetle or flour beetle (Tribolium confusum; Coleoptera) is another common pest. It is one of the most destructive insect pests for grain and other food products stored in silos, warehouse, grocery stores and homes. Aconthoscelides obtectus (Coleoptera), commonly known as the bean weevil feed on beans, vetches and other leguminous plants. Therefore, A. obtectus is considered a pest species. Bean weevils are originally native to Central America; however, they have been spread around the world by grain shipments $[7,8]$. Synthetic insecticides and fumigants are the often preferred chemicals to control of harmful pests. It is well known that the majority of the synthetic chemicals used for various purposes have some harmful effects against to environment and living organisms. Recently, natural agents have been considered as alternatives to reduce the undesirable effects of synthetic chemicals to the environment and for living organisms. Furthermore, increased public concern on the residual toxicity of insecticides and the occurrence of insecticide resistant insect strains calls for new approaches to control stored product insect pests [9]. Therefore, there is a need for alternative safe insecticides or repellents for use on food grain $[10,11]$.

Olea europea L., known as the olive, a species of small tree of Oleaceae family distributed through the Africa, the Mediterranean Basin from Portugal to the Levant, South Asia, east of China and the Canary Islands, Mauritius and Reunion. O. europaea L. has been widely cultivated through the Mediterranean countries such as Turkey, Spain, Portugal, Italy and Greece. There have been characterized about 16 species of Olea genus in the World flora. It is a very long-lived tree and it can live up to 2000 years. The olive leaves contain tannins, essential oil, organic acids and resin. Infusions $(5 \%)$ of the leaves and body shell of olive used as an appetizing, diuretic and antipyretic in the alternative medicine in Turkey [12]. It also used in the treatment of diabetes, dermocosmetic purposes and as a pressure regulator. Olive shampoo prevents hair loss, ensures rapid hair growth, helps to repair lesions in the scalp and prevents dandruff. Solid and liquid soaps, shaver gel, baby shampoo produced from the olive oil protect skin against negative external factors. The leaves of the olive are rich in phenolic compounds, in particular oleuropein which have important biological properties [1318]. Oleuropein content decreases during maturation of the fruits. It has been shown that oleuropein content of the olive fruit can access $14 \%$ of dry matter in young fruits [19]. According to the literature survey, it has been reported that crude extract of the olive leaves and its some phenolic compounds have antioxidant [10,19,20-23], antimicrobial [23] and anticholinesterase activities [24].

Measurement of serum enzyme activities is an important parameter in determining the impact of foreign agents on fish [25]. Therefore serum enzymes levels such as cholinesterases (ACHE and BCHE), alanine aminotransferase (ALT), aspartate aminotransferase (AST), lactate dehydrogenase (LDH) and alkaline phosphatase (ALP) have been accepted as biochemical markers [26,27]. ALT (EC 2.6.1.2) and AST (EC 2.6.1.1) are the intracellular and the most important enzymes involved in amino 
acid metabolism and therefore the increase of these enzymes in blood serum is considered as an indicator of trauma or liver damage [28]. Nile tilapia has long been grown as food for human consumption. Despite being Africa's endemic fish, distribution (cultivation) area of Nile tilapia is extended bringing the tropical and subtropical regions.

Nowadays, treatment with natural medicine including herbal crude extract and their pure metabolites has become important [5,6]. Although it is preferred the mice and/or rats for biological activity studies, recently other organisms have become important $[5,6,29]$. Numerous reports show that herbal extracts and their pure metabolites increase fish growth, the nutritional value of fish and also strengthening defense system [4,6,29-32]. According to our literature survey, there were no records on the effects of Olea europea metabolites on serum biochemical parameters and some ions concentrations of Nile tilapia and the insecticidal properties of the olive leaf extracts and its pure metabolites against the stored pests, $S$. granarius, T. confusum and A. obtectus. Therefore, the aims of this study were i) to isolate the characteristic secoiridoid component, oleuropein and other metabolites, ii) to determine their chemical structures by UV, IR, ${ }^{1} \mathrm{H}-\mathrm{NMR},{ }^{13} \mathrm{C}-\mathrm{NMR}, 1 \mathrm{D}$ and $2 \mathrm{D}-$ NMR spectroscopic methods, iii) to determine the effect of pure metabolites on some biochemical parameters (ALT, AST, ALP, glucose) and ions levels $(\mathrm{Na}, \mathrm{K}, \mathrm{Ca}, \mathrm{Fe}, \mathrm{Cl})$ in the serum of $O$. niloticus and iv) to evaluate the toxic effects of the methanol and ethyl acetate extracts and pure metabolites of the olive leaf against the adults of three stored pests, S. granarius, $T$. confusum and A. obtectus.

\section{Materials and Methods}

\subsection{General}

Thin layer chromatography (TLC) and prep. PTLC on silica gel 60, silica gel 60F-254 (Merck, precoated plates). The spots on TLC were visualized by UV254 and UV365 and spraying with 1\% vanillin- $\mathrm{H}_{2} \mathrm{SO}_{4}$, followed by heating $\left(105^{\circ} \mathrm{C}\right)$. Column chromatography $(\mathrm{CC})$ was carried out using silica gel 60 (Merck, 70-230 and 230-400 mesh). The FT-IR spectra were recorded within the wavelength ranging between 4000 and $400 \mathrm{~cm}^{-1}$ using Thermoscientific Nicolet iS10 FT-IR spectrometer. The ${ }^{1} \mathrm{H}$ NMR and ${ }^{13} \mathrm{C}$ NMR spectra of the isolated compounds were recorded on a Bruker $400\left({ }^{1} \mathrm{H}\right.$ : 400 and $\left.{ }^{13} \mathrm{C}: 100 \mathrm{MHz}\right)$ spectrometer. $\mathrm{CDCl}_{3}$, and $\mathrm{CD}_{3} \mathrm{OD}$ were used as solvent, and $\mathrm{Me}_{4} \mathrm{Si}$ was used the internal standard for the NMR analyses. $\delta$ in ppm relative to as an internal standard, $J$ in $\mathrm{Hz}$.

\subsection{Plant Material, Extraction and Isolation}

The leaves of $O$. europea were collected from Kilis region in Turkey. A dried and powdered sample $(300 \mathrm{~g})$ was extracted with ethyl alcohol (1L x 5). After filtration, ethyl alcohol was removed under vacuum using a rotary evaporator to yield $85 \mathrm{~g}$ (\% yield: 28.3 ) of a dark brown residue. This residue was extracted with ethyl acetate $(250 \mathrm{ml} \mathrm{x} \mathrm{4)} \mathrm{to} \mathrm{remove} \mathrm{the} \mathrm{chlorophyll} \mathrm{and} \mathrm{other} \mathrm{nonpolar}$ compounds in the extract and then an ethyl acetate soluble residue $(40 \mathrm{~g})$ and ethyl acetate-insoluble residue ( $45 \mathrm{~g})$ were obtained. The ethyl acetate-insoluble residue ( $45 \mathrm{~g})$ was fractioned on silica gel $\mathrm{CC}(250 \mathrm{~g}, 700-230 \mathrm{mesh})$ using $\mathrm{CH}_{2} \mathrm{Cl}_{2}-\mathrm{MeOH}(8: 2)$ and then total 60 fractions were collected. The fractions were checked by TLC using $\mathrm{CH}_{2} \mathrm{Cl}_{2}-\mathrm{MeOH}(8: 2), \mathrm{CHCl}_{3}$-EtOAc (7:3), hexane- ethyl acetate (6:4) and the fractions contained same compounds were combined with each other. Thus, the ethyl acetate-insoluble residue was fractioned into four fractions (A-D). There was no chromatographic study on fraction A (6.4g) since it contained only chlorophyll. Fraction B (10.5 g) was combined with the ethyl acetate soluble fraction since they contained same compounds on TLC. Fraction C (15.5g) was determined to a major compound (1) monitoring by TLC and this fraction was further subjected to silica gel CC (150g, 70-230 mesh) eluting with $\mathrm{CH}_{2} \mathrm{Cl}_{2}-\mathrm{MeOH}(9: 1)$. Thus, compound 1 (4.75g) was purified. Fraction D contained mainly two compounds besides compound 1. Fr. D (6.5g) was 
subjected to silica gel $\mathrm{CC}\left(125 \mathrm{~g}, 70-230\right.$ mesh) and eluted with $\mathrm{CH}_{2} \mathrm{Cl}_{2}-\mathrm{MeOH}$ (7.5:2.5) to yield compounds $1(1.5 \mathrm{~g})$ and a trisaccharide $(1.0 \mathrm{~g})$.

In order to remove chlorophyll from the ethyl acetate-soluble residue, it $(50.5 \mathrm{~g})$ was quickly treated with $n$-hexane $(250 \mathrm{ml} \times 3), n$-hexane soluble part was removed and a greenish amorphous solid was obtained $(35.0 \mathrm{~g})$. To isolate metabolites the $n$-hexane-insoluble residue, it $(35.0 \mathrm{~g})$ was

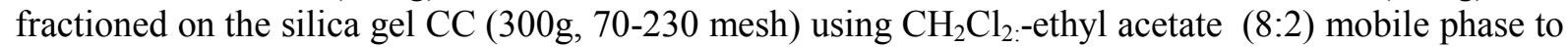
giving four fractions (A-D) as Fr. A (6.3g), Fr. B (9.8g), Fr. C (12.3g), and Fr. D (3.6g). Fraction C $(12.3 \mathrm{~g})$ was contain only two major compounds (compounds $\mathbf{2}$ and $\mathbf{3}$ ) when it was checked by TLC. This fraction was fractioned on silica gel CC (200g, 70-230 mesh) using $\mathrm{CHCl}_{3}$-EtOAc (8:2 and 6:4) to afford compounds $\mathbf{2}(4.88 \mathrm{~g})$ and $\mathbf{3}(1.65 \mathrm{~g})$. Compounds $\mathbf{4}$ and $\mathbf{5}$ were isolated over silica gel CC (150 g, 230-400 mesh) eluting with $\mathrm{CH}_{2} \mathrm{Cl}_{2}$ ethyl acetate (8:2) mobile phase as a mixture (2.52g) from fraction B (9.8g). According to TLC analyses, compounds $\mathbf{4}$ and $\mathbf{5}$ have same Rf values and these compounds were not separated from each one with chromatographic methods. Therefore, these compounds were used as a mixture in biological assays.

The spectral data of the pure compounds are given in below.

Oleuropein (1): Brownish amorphs. IR $v_{\max }\left(\right.$ ATR): $3347 \mathrm{~cm}^{-1}$ (br. -OH), 2800-3000 $\mathrm{cm}^{-1}(-\mathrm{CH})$, $1700 \mathrm{~cm}^{-1}$ and $1627 \mathrm{~cm}^{-1}$ (two $\mathrm{C}=\mathrm{O}$ vibrations), $1400-1600 \mathrm{~cm}^{-1}\left(\mathrm{C}=\mathrm{C}\right.$ vibration bands), $1069 \mathrm{~cm}^{-1}$ (CO). ${ }^{1} \mathrm{H}$ NMR $(\delta, \mathrm{ppm})\left(\mathrm{DMSO}^{-} \mathrm{d}_{6}\right): 7.47 \mathrm{ppm}(s, \mathrm{H}-\mathrm{C}(3)) ; 6.63\left(d, J=7.96 \mathrm{~Hz}, \mathrm{H}-7^{\prime}\right) ; 6.59$ (s, H-4'); $6.46\left(d, J=8.00 \mathrm{~Hz}, \mathrm{H}-8^{\prime}\right) ; 5.92(q, J=13.1 \mathrm{~Hz}, \mathrm{H}-8) ; 5.82(s, \mathrm{H}-1) ; 4.65(d, J=7.76 \mathrm{~Hz}, \mathrm{H}-1 ") ; 4.13$ ( $t$, $\left.J=8.4 \mathrm{~Hz}, \mathrm{H}-1^{\prime}\right) ; 3.79\left(d d, J_{I}=13.2 \mathrm{~Hz}, J_{2}=4.5 \mathrm{~Hz}, \mathrm{H}-5\right) ; 3.65$ ( $\left.s,-\mathrm{OMe}\right) ; 3.40-3.70\left(m, \mathrm{H}-2 ", 3^{\prime \prime}, 4 "\right.$ and $\left.5^{\prime \prime}\right) ; 3.05-3.25$ (m, H-6"); 2.68 ( $\left.t, \mathrm{H}-2^{\prime}\right) ; 2.36$ ( $\left.d, J=9.20 \mathrm{~Hz}, \mathrm{H}-6 \mathrm{a}\right) ; 2.33$ (d, J=9.10 Hz, H-6b); 1.66 (d, $J=6.24 \mathrm{~Hz}, \mathrm{Me}-10) .{ }^{13} \mathrm{C}$ NMR $(\delta, \mathrm{ppm})\left(\right.$ DMSO-d $\left._{6}\right): 171.5$ (7); $167.0(11) ; 154.0(3) ; 145.2\left(5^{\prime}\right) ; 143.9$ (6'); $129.3\left(3^{\prime}\right) ; 129.2(6) ; 123.7(8) ; 120.2\left(8^{\prime}\right) ; 116.5\left(4^{\prime}\right) ; 115.9$ (7'); 108.1 (4); $99.3(1 ") ; 93.5(1)$; 77.3 (5"); $76.6\left(3^{\prime \prime}\right) ; 73.5\left(2^{\prime \prime}\right) ; 70.2\left(4^{\prime \prime}\right) ; 65.6\left(1^{\prime}\right) ; 61.1$ (6"); 51.8 (OMe), 49.0 (9); 33.9 (2'); 30.6 (5); $13.3(10)$.

Oleanolic acid (2): White amorphs. IR $v_{\max }$ (ATR): $3393 \mathrm{~cm}^{-1}$ (br. -OH), 2800-3000 $\mathrm{cm}^{-1}$ (strong $-\mathrm{CH}), 1687 \mathrm{~cm}^{-1}(\mathrm{C}=\mathrm{O}), 1028 \mathrm{~cm}^{-1}(\mathrm{C}-\mathrm{O}) .{ }^{1} \mathrm{H}-\mathrm{NMR}(\delta, \mathrm{ppm})\left(\mathrm{DMSO}-\mathrm{d}_{6}\right): 5.39(t, J=2.88$ and $3.12 \mathrm{~Hz}$, $\mathrm{H}-12) ; 3.34\left(d d, J_{I}=7.58 \mathrm{~Hz}, J_{2}=6.50\right.$ and $\left.6.40 \mathrm{~Hz}, \mathrm{H}-3\right) ; 3.19\left(d d, J_{I}=13.74 \mathrm{~Hz}, J_{2}=3.96\right.$ and $3.84 \mathrm{~Hz}$, $\mathrm{H}-18) ; 2.05\left(t d, J_{I}=10.66 \mathrm{~Hz}, J_{2}=2.92\right.$ and $\left.2.36 \mathrm{~Hz}, \mathrm{H}-2\right) ; 1.88(m, \mathrm{H}-11) ; 1.60(t, J=8.80 \mathrm{~Hz}, \mathrm{H}-9)$; $1.48(m, \mathrm{H}-6) .{ }^{13} \mathrm{C}$ NMR $(\delta, \mathrm{ppm})\left(\mathrm{DMSO}_{6}\right): 179.9(28) ; 144.6(13) ; 122.3(12) ; 77.9(3) ; 55.6(5)$; 47.9 (9); 46.4 (19); 46.3 (17); 42.0 (14), 41.8 (18); 39.6 (16); 39.2 (4); 38.8 (10); 37.2 (8); 34.0 (21), 33.1 (29 and 22); 33.0 (7); 30.8 (20); 28.6 (23); 28.1 (15); 27.8 (1); 26.0 (27); 23.6 (11 and 30); 23.5 (2); $18.6(6) ; 17.2(26) ; 16.3(24) ; 15.4(25)$.

Maslinic acid (3): White amorphs. IR $v_{\max }$ (ATR): $3384 \mathrm{~cm}^{-1}$ (br -OH), 2800-3000 $\mathrm{cm}^{-1}$ (strong $\mathrm{CH}), 1687 \mathrm{~cm}^{-1}(\mathrm{C}=\mathrm{O}), 1049 \mathrm{~cm}^{-1}(\mathrm{C}-\mathrm{O}) .{ }^{1} \mathrm{H}-\mathrm{NMR}(\delta, \mathrm{ppm})\left(\mathrm{DMSO}_{6}\right): 5.90(\mathrm{bs}, \mathrm{H}-5) ; 3.98 \mathrm{ppm}(d t$, $J_{I}=10.32 \mathrm{~Hz}, J_{2}=4.36$ and $\left.4.32 \mathrm{~Hz}, \mathrm{H}-2\right) ; 3.28(d, J=9.36 \mathrm{~Hz}, \mathrm{H}-18) ; 3.19\left(d d, J_{I}=13.68 \mathrm{~Hz}, J_{2}=4.24\right.$ $\mathrm{Hz}, \mathrm{H}-3) ; 1.16$ ( $s, \mathrm{Me}-27)$ ); 1.15 ( $s, \mathrm{Me}-23) ; 0.97$ ( $s, \mathrm{Me}-25) ; 0.91$ ( $s, \mathrm{Me}-30) ; 0.90$ (s, Me-29); 0.88 ( $s$, Me-24); $0.84(s, \mathrm{Me}-26) .{ }^{13} \mathrm{C}-\mathrm{NMR}(\delta, \mathrm{ppm})\left(\mathrm{DMSO}_{6}\right)$ : $179.9(28) ; 144.6(13) ; 122.2(12) ; 83.6(3)$; 68.4 (2); 55.7 (5) 47.9 (9); 47.5 (1); 46.4 (17); 46.2 (19); 42.0 (14); 41.8 (18); 39.6 (8 and 4); 38.3 (10); 34.0 (21); 33.0 (29); 32.9 (22 and 7); 30.7 (20); 29.1 (23); 28.1 (15); 25.9 (27); 23.7 (11); 23.5 (30); 23.4 (16); $18.6(6) ; 17.4(26) ; 17.2(25) ; 16.6(24)$.

A mixture of eryhthrodiol (4) and uvaol (5): White amorphs. IR $v_{\max }$ (ATR): $3339 \mathrm{~cm}^{-1}$ (br. $\mathrm{OH}), 2800-3000 \mathrm{~cm}^{-1}$ (strong -CH), $1464 \mathrm{~cm}^{-1}(\mathrm{C}=\mathrm{C}), 1044 \mathrm{~cm}^{-1}(\mathrm{C}-\mathrm{O}) .{ }^{1} \mathrm{H}-\mathrm{NMR}(\delta, \mathrm{ppm})$ (DMSO$\left.\mathrm{d}_{6}\right): 5.18$ and $5.13(s, \mathrm{H}-12) ; 3.52(d, J=10.56 \mathrm{~Hz}, \mathrm{H}-28 \mathrm{a}) ; 3.21(m, \mathrm{H}-3) ; 3.18(d, J=10.84 \mathrm{~Hz}, \mathrm{H}-$ $28 \mathrm{~b}) .{ }^{13} \mathrm{C}-\mathrm{NMR}(\delta, \mathrm{ppm})\left(\mathrm{DMSO}-\mathrm{d}_{6}\right): 144.2$ and $138.7(13) ; 125.0$ and $122.3(12) ; 79.0(3) ; 69.9$ and 69.7 (28); 55.2 and $54.0(5) ; 47.7$ and $46.5(9) ; 42.3 ; 42.0 ; 41.7 ; 40.0 ; 39.8 ; 39.4 ; 38.8 ; 38.6 ; 38.0$; 
$36.9 ; 35.2 ; 34.1 ; 33.2 ; 32.8 ; 32.6 ; 31.9 ; 31.0 ; 30.9 ; 30.6 ; 29.7 ; 29.4 ; 28.2 ; 28.1 ; 27.2 ; 26.0 ; 25.9 ; 25.6$; $23.6 ; 23.5 ; 23.4 ; 23.3 ; 22.7 ; 22.0 ; 21.3 ; 18.3 ; 17.3 ; 16.8 ; 16.7 ; 15.7 ; 15.6 ; 15.5$.

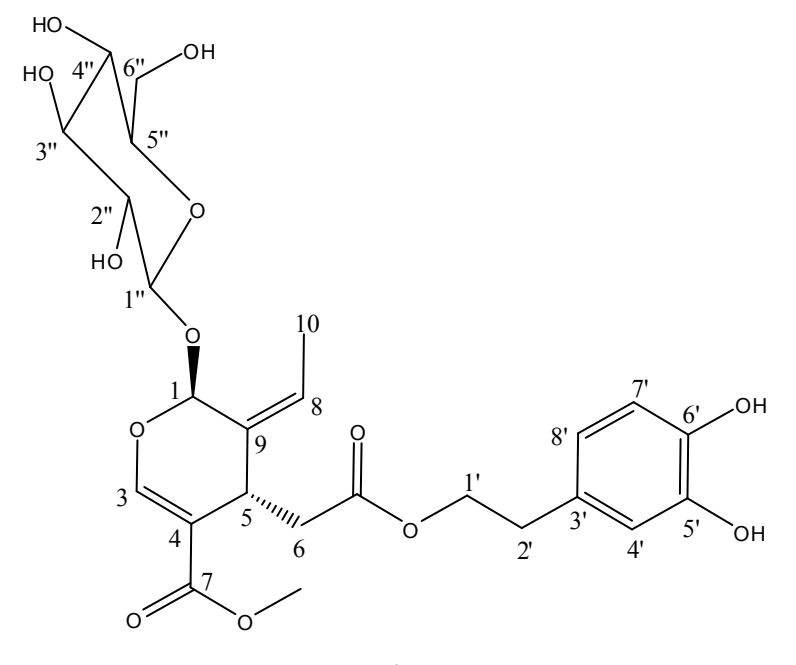

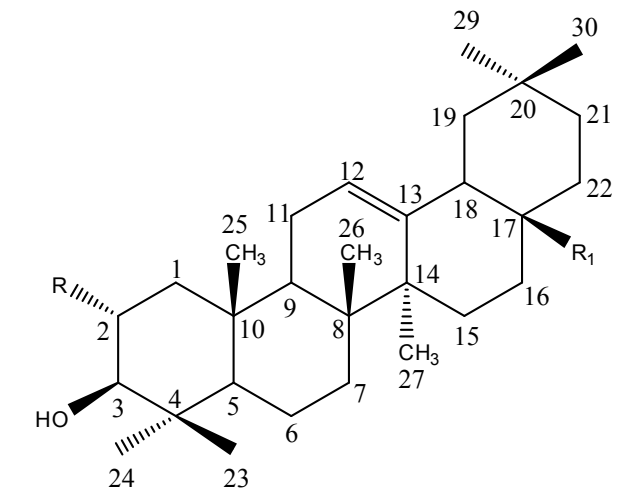

$\underline{\mathbf{R}}$

$\mathrm{H}$

$\mathrm{OH}$

H

$\begin{array}{lll}\mathbf{2} & \mathrm{H} & \mathrm{COOH} \\ \mathbf{3} & \mathrm{OH} & \mathrm{COOH} \\ \mathbf{4} & \mathrm{H} & \mathrm{CH}_{2} \mathrm{OH}\end{array}$

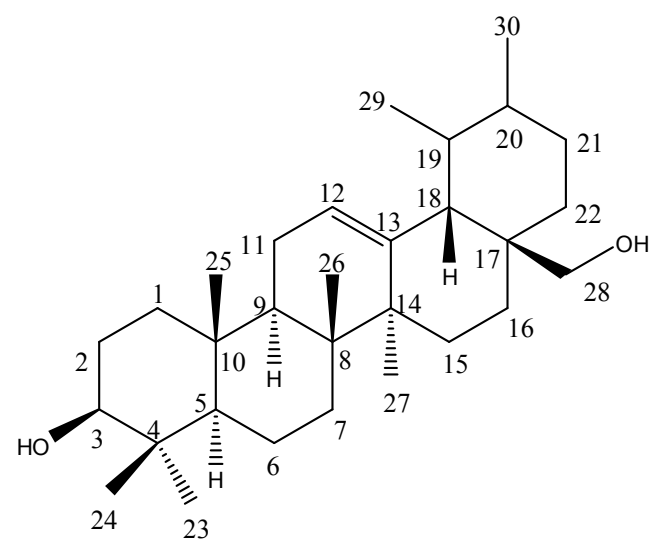

5

Figure 1. The chemical structures of the leaf metabolites of olive (O. europea L.).

\subsection{Statistical Analyses}

Data are presented as mean \pm standard error. For the statistical analysis, it was used one-way analysis of variance (ANOVA) followed by Student Newman-Keul's test using SPSS 10.0 statistical software (SPSS Inc., Chicago, IL). Differences were considered significant if $p<0.05$. LC 50 values were determined in the $72 \mathrm{~h}$, in order to determine the toxic effects of substances used as insecticide by probit analysis. 


\section{Results and Discussion}

\subsection{Chemical composition of O. europea leaves}

The fractionation of the ethanol and ethyl acetate extracts of $O$. europea leaves by column and thin layer chromatography methods was afforded to isolation of known metabolites, one secoiridoid (1) and four triterpenoids $(\mathbf{2}, \mathbf{3}, \mathbf{4}$ and 5). The chemical structures of five known compounds were elucidated by FT-IR, ${ }^{1} \mathrm{H}-$ and ${ }^{13} \mathrm{C}-\mathrm{NMR}, 1 \mathrm{D}-\mathrm{NMR}$ (DEPT, APT), 2D-NMR $\left({ }^{1} \mathrm{H}-{ }^{1} \mathrm{H}\right.$ COSY, HMQC and HMBC) spectroscopic methods. The chemical structures of the metabolites were also confirmed by comparison of their spectral data with those reported in the literature, i.e. as oleuropein (1) [1819,21,24], oleanolic acid (2) [35-37], maslinic acid (3) [38-40], erythrodiol (4) and uvaol (5) [36,41] (Figure 1). It is well known that oleuropein (1), erythrodiol (4), uvaol (5), are the characteristic components of the olive leaf and fruits $[35,39,42,43]$. Ursolic acid is another characteristic component of the olive leaves besides oleanolic acid (2) and maslinic acid (3) [38,39-43], whereas ursolic acid was not found in the present study. On the other hand, compounds $\mathbf{4}$ and $\mathbf{5}$ (erythrodiol and uvaol) were isolated as an only one spot on TLC due to their similar polarity (Figure 1). Their ${ }^{1} \mathrm{H}$ and ${ }^{13} \mathrm{C}$ NMR spectral data showed that it is a mixture of two compounds, erythrodiol and uvaol $(\mathbf{4}+\mathbf{5})$. There were many carbon and hydrogen signals at its ${ }^{13} \mathrm{C}$ and ${ }^{1} \mathrm{H}$ NMR signal belonging to two compounds. As can be seen from Figure 1, these compounds have similar chemical structures, polarities and same chemical formulas and weights. Therefore, these compounds were not separated from each one with chromatographic methods. These findings are also in accordance with previous published data [36,37].

\subsection{Bioassays in Nile tilapia}

The pure metabolites were added at two concentrations $(1 \mathrm{~g} / 100 \mathrm{~g}$ feed and $4 \mathrm{~g} / 100 \mathrm{~g}$ feed $)$ into fish feed. Nile tilapias were fed twice a day with the feed during 96 hours. ALT, AST, ALP enzymes activities, and glucose and some ion levels $(\mathrm{Na}, \mathrm{K}, \mathrm{Ca}$ and $\mathrm{Cl})$ in the blood serum of fishes were determined. In general, levels of ALT, ALP, AST enzymes and glucose in the serums of fishes fed with pure compounds were found to be high as compared with the control group (Table 1 and Figure S1). In living organisms, transaminase or aminotransferase enzymes such as ALT and AST play important roles catalyzing the reversible reactions between amino acids and $\alpha$-keto acids. Serum ALT, AST and their ratio (AST/ALT) are used as important indicators of liver cell damage or hepatotoxicity [28,44-46]. As shown in Figure S1 and Table 1, oleuropein (1) did not significantly affect the ALT enzyme level in the Nile tilapia serum, whereas all of the other tested metabolites increased the level of this enzyme without dose dependent. In particular, the low concentration of $(1 \mathrm{~g} / 100 \mathrm{~g}$ feed) of maslinic acid (3) was determined as most increasing application of the ALT level. While the low concentration of oleanolic acid (2) increased the level of ALT, its high concentration did not exhibit a statistically significant effect (Figure S1). These results show that all metabolites except for oleuropein (1) are the toxic agents for liver of Nile tilapia [25,26,28,44-46]. In living organisms, AST is another enzyme used as an indicator for tissue damages of some organs including the liver, heart muscle, kidney and brain [28,44-46]. The current results on the AST enzyme levels in serums of Nile tilapia showed that all treatments significantly increased the level of AST enzyme as compared with control group $(p<0.05)$ (Table 1 and Figure S1). The increase of the level of this enzyme can be attributed to toxic effects of olive leaf metabolites against one and/or more ones of the tissues of liver, heart muscle, kidney and brain of the Nile tilapia. Oleuropein (1) did not significantly affect the level of ALT, whereas it increased the AST level of fish (Table 1 and Figure S1). These findings suggested that oleuropein (1) is a damaging agent to the other organ tissues rather than the liver of Nile tilapia $[27,28,44-46]$. 
Table 1. Effects of the olive leaf metabolites on some enzymes and glucose levels in serums of tilapia.

\begin{tabular}{|c|c|c|c|c|c|}
\hline Compounds & Dose & $\begin{array}{l}\text { ALT } \\
(\mathrm{U} / \mathrm{L})\end{array}$ & $\begin{array}{l}\text { AST } \\
(\mathrm{U} / \mathrm{L})\end{array}$ & $\begin{array}{l}\text { ALP } \\
(\mathrm{U} / \mathrm{L})\end{array}$ & $\begin{array}{l}\text { Glucose } \\
\text { (mg/dL) }\end{array}$ \\
\hline \multirow[t]{2}{*}{ Oleuropein (1) } & $1 \mathrm{~g} / 100 \mathrm{~g}$ feed & $8 \pm 0$ & $311 \pm 4^{*}$ & $27 \pm 2 *$ & $64 \pm 1^{*}$ \\
\hline & $4 \mathrm{~g} / 100 \mathrm{~g}$ feed & $10 \pm 1$ & $464 \pm 6^{*}$ & $24 \pm 1$ & $66 \pm 1 *$ \\
\hline \multirow[t]{2}{*}{ Oleanolic acid (2) } & $1 \mathrm{~g} / 100 \mathrm{~g}$ feed & $14 \pm 1 *$ & $319 \pm 8^{*}$ & $28 \pm 2 *$ & $83 \pm 5^{*}$ \\
\hline & $4 \mathrm{~g} / 100 \mathrm{~g}$ feed & $11 \pm 1$ & $358 \pm 6^{*}$ & $24 \pm 1$ & $79 \pm 4^{*}$ \\
\hline \multirow[t]{2}{*}{ Maslinic acid (3) } & $1 \mathrm{~g} / 100 \mathrm{~g}$ feed & $25 \pm 2 *$ & $367 \pm 5^{*}$ & $25 \pm 2$ & $64 \pm 2 *$ \\
\hline & $4 \mathrm{~g} / 100 \mathrm{~g}$ feed & $15 \pm 1 *$ & $313 \pm 4^{*}$ & $30 \pm 3 *$ & $63 \pm 1 *$ \\
\hline \multirow[t]{2}{*}{ Erythrodiol +uvaol (4+5) } & $1 \mathrm{~g} / 100 \mathrm{~g}$ feed & $17 \pm 1 *$ & $300 \pm 2 *$ & $31 \pm 1 *$ & $69 \pm 2 *$ \\
\hline & $4 \mathrm{~g} / 100 \mathrm{~g}$ feed & $18 \pm 1 *$ & $283 \pm 5^{*}$ & $30 \pm 2 *$ & $65 \pm 2 *$ \\
\hline \multirow[t]{2}{*}{ Trisaccharide } & $1 \mathrm{~g} / 100 \mathrm{~g}$ feed & $14 \pm 1 *$ & $328 \pm 6^{*}$ & $32 \pm 2 *$ & $84 \pm 5^{*}$ \\
\hline & $4 \mathrm{~g} / 100 \mathrm{~g}$ feed & $20 \pm 2 *$ & $354 \pm 6^{*}$ & $26 \pm 2 *$ & $71 \pm 5^{*}$ \\
\hline Control & Only feed & $10 \pm 1$ & $265 \pm 6$ & $22 \pm 1$ & $43 \pm 2$ \\
\hline
\end{tabular}

* Statistically significant from the control.

ALP is a hydrolase enzyme and catalysis removing reactions of phosphate groups from many type molecules such as nucleotides, proteins and alkaloids. This process is called dephosphorylation and it is most effective in an alkaline environment. ALP is synthesized by bone, liver, intestine and placenta in living organisms (in humans) and it is excreted via the bile. The increasing level of this enzyme in the serum point out there is a tissue damage in bone, liver and biliary tract $[28,44-46]$. As can be seen from Table 1 and Figure S1, in general, ALP levels were found to be high level in the groups treated with the leaf olive metabolites as compared with control groups. The high concentrations of oleuropein (1) and oleanolic acid (2) did not affect significantly the level of ALP. Nevertheless, oleuropein (1) isolated from the leaves of Olea ferruginea was found to be a potent inhibitor of ALP enzyme [18]. Based on these findings, it can be concluded that the olive leaf metabolites have pathogenic effect against bone, liver and biliary tract of Nile tilapia [27,28,44-46].

The glucose levels in the groups treated with the olive leaf metabolites of Nile tilapia serums were found to be high in comparison to control group $(p<0.05)$ (Table 1 and Figure S1). In particular, oleanolic acid (2) and a trisaccharide increased the glucose level about two times as compared to that of the control group (Figure S1). In living organisms, the regulation of the serum glucose level takes place over a complex process that involved some hormones and enzymes $[47,48]$. The most important hormone in the glucose metabolism is the insulin secreted by pancreas [49,50]. The liver is a very important organ in carbohydrate, fat and protein metabolisms. In the current study, it can be concluded that uncharacterized carbohydrate increased the glucose level undergoes metabolism in the liver. Moreover, carbohydrate, fat and protein metabolisms can affect negatively as a result of tissue damages occurring in the some organs such as the liver, gall bladder and kidney. The current results indicated that the leaf metabolites of the olive influenced the ALT, AST and ALP enzymes levels in varying proportions used as an indicator of the tissue injuries of the liver, kidney and gall bladder. The high glucose levels in the groups treated with the olive leaf metabolites can be attributed to irregular carbohydrate, fat and protein metabolism as a result of the tissue injuries of the liver, kidney and gall bladder in Nile tilapia [47-50].

Biochemical analyses of the serum and blood plasma provide important information for researchers about electrolytes besides metabolic pathway and some internal organs such as the liver and kidney $[47,48]$. The electrolytes including $\mathrm{Na}, \mathrm{Cl}, \mathrm{K}$ and $\mathrm{Ca}$ are the essential minerals for growth and ion balance of fishes. These minerals are supplied from the aquatic environment by the gill of fishes [51]. Diverse agents taken outside via diet and/or gills may lead to change the electrolyte levels and ion balance [52]. The effects of the olive leaf metabolites on the $\mathrm{Na}, \mathrm{Cl}, \mathrm{K}$ and $\mathrm{Ca}$ concentrations were summarized in Table 2. As can be seen from this table, the olive leaf metabolites were exhibited regular effects on the serum ion concentrations of Nile tilapia. For instance, $4 \mathrm{~g} / 100 \mathrm{~g}$ feed administration of oleanolic acid (2) significantly reduced the concentrations of all ions as compared with control group $(p<0.05)$. However, oleuropein (1), trisaccharide and the mixture of erythrodiol (4) 
and uvaol (5) did not exhibit any reducing or increasing effect on the ions concentrations (Table 2). Fe concentration in the serums of the fish treated with maslinic acid (3) $(1 \mathrm{~g} / 100 \mathrm{~g}$ feed) was found to be low concentration in comparison to control group. Furthermore, Ca concentration in the maslinic acid group ( $4 \mathrm{~g} / 100 \mathrm{~g}$ feed) was measured as high concentration than control group (Table 2).

Table 2. Effects of the olive leaf metabolites on some ion concentrations in serums of Nile tilapia.

\begin{tabular}{lllllll}
\hline Compounds & Dose & $\begin{array}{l}\mathrm{Na} \\
(\mathrm{mmol} / \mathrm{L})\end{array}$ & $\begin{array}{l}\mathrm{Cl} \\
(\mathrm{mmol} / \mathrm{L})\end{array}$ & $\begin{array}{l}\mathrm{Fe} \\
(\mu \mathrm{g} / \mathrm{L})\end{array}$ & $\begin{array}{l}\mathrm{Ca} \\
(\mathrm{mg} / \mathrm{dL})\end{array}$ & $\begin{array}{l}\mathrm{K} \\
(\mathrm{mmol} / \mathrm{L})\end{array}$ \\
\hline Oleuropein (1) & $1 \mathrm{~g} / 100 \mathrm{~g}$ feed & $149 \pm 2$ & $128 \pm 2$ & $80 \pm 1$ & $14.0 \pm 1.2$ & $5.10 \pm 0.20$ \\
& $4 \mathrm{~g} / 100 \mathrm{~g}$ feed & $147 \pm 2$ & $126 \pm 2$ & $84 \pm 2$ & $11.1 \pm 1.3$ & $6.34 \pm 0.20$ \\
Oleanolic acid (2) & $1 \mathrm{~g} / 100 \mathrm{~g}$ feed & $147 \pm 2$ & $125 \pm 3$ & $68 \pm 2^{*}$ & $13.6 \pm 2.1$ & $5.28 \pm 0.10$ \\
& $4 \mathrm{~g} / 100 \mathrm{~g}$ feed & $141 \pm 1^{*}$ & $122 \pm 3^{*}$ & $64 \pm 1^{*}$ & $9.20 \pm 0,1^{*}$ & $4.01 \pm 0.10^{*}$ \\
Maslinic acid (3) & $1 \mathrm{~g} / 100 \mathrm{~g}$ feed & $151 \pm 2$ & $133 \pm 1$ & $50 \pm 2^{*}$ & $11.1 \pm 1.1$ & $5.47 \pm 0.10$ \\
& $4 \mathrm{~g} / 100 \mathrm{~g}$ feed & $150 \pm 2$ & $130 \pm 2$ & $70 \pm 2$ & $14.6 \pm 0.1^{*}$ & $5.18 \pm 0.20$ \\
Erythrodiol +uvaol & $1 \mathrm{~g} / 100 \mathrm{~g}$ feed & $153 \pm 1$ & $132 \pm 2$ & $80 \pm 2$ & $11.1 \pm 0.1$ & $5.15 \pm 0.20$ \\
$(\mathbf{4}+\mathbf{5})$ & $4 \mathrm{~g} / 100 \mathrm{~g}$ feed & $152 \pm 2$ & $130 \pm 3$ & $65 \pm 1^{*}$ & $11.1 \pm 0.1$ & $4.70 \pm 0.20$ \\
Trisaccharide & $1 \mathrm{~g} / 100 \mathrm{~g}$ feed & $155 \pm 2$ & $134 \pm 5$ & $77 \pm 1$ & $13.7 \pm 1.1$ & $5.40 \pm 0.10$ \\
& $4 \mathrm{~g} / 100 \mathrm{~g}$ feed & $152 \pm 2$ & $133 \pm 4$ & $78 \pm 2$ & $10.2 \pm 1.2$ & $5.46 \pm 0.20$ \\
Control & Only feed & $\mathbf{1 5 2} \pm \mathbf{3}$ & $\mathbf{1 3 7} \pm \mathbf{2}$ & $\mathbf{7 8} \pm \mathbf{2}$ & $\mathbf{1 2 . 4} \pm \mathbf{1 . 1}$ & $\mathbf{5 . 4 5} \pm \mathbf{0 . 2 0}$ \\
\hline
\end{tabular}

* Statistically significant from the control.

\subsection{Insecticidal Properties of the Extracts and Pure Olive Leaf Metabolites}

The contact toxic effects of the ethyl acetate and methanol extracts of olive leaf and its metabolites, oleuropein (1), oleanolic acid (2), maslinic acid (3) and a mixture of erythrodiol (4) and uvaol (5) of the olive leaf against the adults of $S$. granarius (grain weevil), $T$. confusum (the confused flour beetle) and A. obtectus (bean weevil) were evaluated (Tables 3-5). Three different concentrations, 2.5, 5.0 and $7.5 \mathrm{mg} /$ Petri dish concentrations of the extracts and the olive leaf metabolites were tested for toxic effects correspondence to 125,250 and $375 \mu \mathrm{g}$ per insect, respectively. The same concentrations $(2.5,5.0$ and $7.5 \mathrm{mg} /$ Petri dish concentrations) of the commercial insecticide, DDVP was used as positive control. The mean mortalities of the extracts of olive leaf and olive leaf metabolites against three stored pests after 96h treatments times were also presented in Figures S2-S4. As can be seen from Tables 3-5 and Figures S2-S4, the mortalities of the insects increased with increase in the concentrations of the extracts and the leaf metabolites of the olive and treatment times. These results show that the insecticidal effects of the extracts and metabolites are dose dependent manner. The extracts and olive leaf metabolites, oleuropein (1), oleanolic acid (2), maslinic acid (3) and a mixture of erythrodiol (4) and uvaol (5) have varying degrees of the toxic effects (Tables 3-5 and Figures S2-S4). However, the toxicities of the leaf extracts and leaf metabolites of the olive were found lower than the toxicities of the commercial insecticide, DDVP against the adults of the tested pests. Dichlorvos caused complete mortality of the insects after 48 hours of treatments, whereas the metabolites caused the mortality rates 16.7-63.3 \%, 13.3-67.0\% and $26.7-59.0 \%$ of $S$. granarius, $T$. confusum and A. obtectus, respectively after $48 \mathrm{~h}$ treatments (Tables 3-5, Figures S2-S4). As can be seen from Table 3, erythrodiol+uvaol (compounds 4+5) application against $S$. granarius draws attention. While the toxicity of this application was found to be low within first 48 hours as compared with other applications, its toxic effects increased suddenly after $48 \mathrm{~h}$ of applications. The toxicity of uvaol+erythrodiol $(\mathbf{4}+\mathbf{5})$ application was higher than other applications after $48 \mathrm{~h}$ of application. 
Table 3. Toxic effects of the extracts and the olive leaf metabolites against $S$. granarius.

\begin{tabular}{|c|c|c|c|c|c|}
\hline \multirow[b]{3}{*}{ Treatments } & \multirow[b]{3}{*}{$\begin{array}{c}\text { Conc. } \\
\text { (mg/Petri) }\end{array}$} & \multicolumn{4}{|c|}{ Mean mortality (\%) } \\
\hline & & \multicolumn{4}{|c|}{ Exposure time (h) } \\
\hline & & 24 & 48 & 72 & 96 \\
\hline \multirow{3}{*}{$\mathrm{MeOH}$ extract } & 2.5 & $30.0 \pm 7.6 * \mathrm{def}$ & $40.0 \pm 5.8 * \mathrm{~cd}$ & $46.7 \pm 3.3 * \mathrm{~cd}$ & $53.3 \pm 1.7 * \mathrm{bc}$ \\
\hline & 5.0 & $35.0 \pm 5.0 * \mathrm{ef}$ & $43.3 \pm 1.7 * \mathrm{~cd}$ & $50.0 \pm 0.0 * \mathrm{cde}$ & $56.7 \pm 1.7 * \mathrm{bc}$ \\
\hline & 7.5 & $40.0 \pm 0.0 * \mathrm{f}$ & $53.3 \pm 7.3 * \mathrm{~d}$ & $63.3 \pm 7.3 * \mathrm{de}$ & $70.0 \pm 5.0 * \mathrm{~cd}$ \\
\hline \multirow{3}{*}{ EtOAC extract } & 2.5 & $13.3 \pm 3.3 \mathrm{abc}$ & $16.7 \pm 4.4 * b$ & $21.7 \pm 4.4 * b$ & $36.7 \pm 4.4 * \mathrm{~b}$ \\
\hline & 5.0 & $21.7 \pm 4.4 *$ bcde & $28.3 \pm 6.0 * \mathrm{bc}$ & $36.7 \pm 4.4 * b c$ & $38.3 \pm 3.3 * \mathrm{~b}$ \\
\hline & 7.5 & $25.0 \pm 7.6 * \mathrm{cdef}$ & $30.0 \pm 7.6 * \mathrm{bc}$ & $35.0 \pm 5.8 * b c$ & $48.3 \pm 7.3 * \mathrm{~b}$ \\
\hline \multirow{3}{*}{ Oleuropein (1) } & 2.5 & $6.7 \pm 1.7 \mathrm{ab}$ & $16.7 \pm 1.7 * b$ & $38.3 \pm 5.3 * b c$ & $43.3 \pm 5.9 * b$ \\
\hline & 5.0 & $33.3 \pm 4.4 * \operatorname{def}$ & $41.7 \pm 1.7^{*} \mathrm{~cd}$ & $45.0 \pm 5.0 * \mathrm{~cd}$ & $45.0 \pm 5.0 * \mathrm{~b}$ \\
\hline & 7.5 & $33.3 \pm 7.7 * \mathrm{def}$ & $45.0 \pm 13.2 * \mathrm{~cd}$ & $50.0 \pm 5.6 * \mathrm{cde}$ & $51.7 \pm 3.7 * \mathrm{bc}$ \\
\hline \multirow{3}{*}{ Oleanolic acid (2) } & 2.5 & $13.3 \pm 1.7 \mathrm{abc}$ & $28.3 \pm 3.3 * b c$ & $36.7 \pm 3.3 * b c$ & $48.3 \pm 3.3 * b$ \\
\hline & 5.0 & $21.7 \pm 7.3 *$ bcde & $38.3 \pm 4.4 * \mathrm{~cd}$ & $45.0 \pm 8.7^{*} \mathrm{~cd}$ & $51.7 \pm 7.7 * \mathrm{bc}$ \\
\hline & 7.5 & $26.7 \pm 6.0 *$ cdef & $41.7 \pm 6.0 * \mathrm{~cd}$ & $48.3 \pm 7.3 *$ cde & $56.7 \pm 6.0 * \mathrm{bc}$ \\
\hline \multirow{3}{*}{ Maslinic acid (3) } & 2.5 & $19.0 \pm 1.0 *$ bcde & $47.0 \pm 1.0 * \mathrm{~cd}$ & $69.0 \pm 0.0 * \mathrm{e}$ & $77.0 \pm 1.0 * \mathrm{cde}$ \\
\hline & 5.0 & $33.0 \pm 1.7 * \operatorname{def}$ & $55.0 \pm 2.7 * \mathrm{~d}$ & $74.0 \pm 1.0 * \mathrm{e}$ & $85.0 \pm 1.0 * \mathrm{de}$ \\
\hline & 7.5 & $41.0 \pm 1.0 * \mathrm{f}$ & $63.0 \pm 1.7 * \mathrm{de}$ & $83.0 \pm 1.0 * \mathrm{ef}$ & $97.0 \pm 2.0 * \mathrm{e}$ \\
\hline \multirow{3}{*}{$\begin{array}{l}\text { Erythrodiol + uvaol } \\
(\mathbf{4}+\mathbf{5})\end{array}$} & 2.5 & $1.7 \pm 1.7 \mathrm{a}$ & $28.3 \pm 3.3 * \mathrm{bc}$ & $50.0 \pm 2.9 *$ cde & $81.7 \pm 6.0 \mathrm{de}$ \\
\hline & 5.0 & $11.7 \pm 1.7 \mathrm{abc}$ & $31.7 \pm 1.7 * \mathrm{bc}$ & $51.7 \pm 1.7 *$ cde & $85.0 \pm 5.8 * \mathrm{de}$ \\
\hline & 7.5 & $18.3 \pm 1.7 * \mathrm{bcd}$ & $38.3 \pm 1.7 * \mathrm{~cd}$ & $66.7 \pm 1.7 * \mathrm{e}$ & $91.7 \pm 1.7 * \mathrm{e}$ \\
\hline \multirow{3}{*}{ Dichlorvos } & 2.5 & $93.3 \pm 1.7 * \mathrm{~g}$ & $100.0 \pm 0.0 * \mathrm{f}$ & $100.0 \pm 0.0 * \mathrm{~g}$ & $100.0 \pm 0.0 * \mathrm{e}$ \\
\hline & 5.0 & $95.0 \pm 0.0 * \mathrm{~g}$ & $100.0 \pm 0.0 * \mathrm{f}$ & $100.0 \pm 0.0 * \mathrm{~g}$ & $100.0 \pm 0.0 * \mathrm{e}$ \\
\hline & 7.5 & $98.3 \pm 1.7 * \mathrm{~g}$ & $100.0 \pm 0.0 * \mathrm{f}$ & $100.0 \pm 0.0 * \mathrm{~g}$ & $100.0 \pm 0.0 * \mathrm{e}$ \\
\hline $\begin{array}{l}\text { Control } \\
\text { (non-treated) }\end{array}$ & - & $0.0 \pm 0.0 \mathrm{a}$ & $0.0 \pm 0.0 \mathrm{a}$ & $0.0 \pm 0.0 \mathrm{a}$ & $0.0 \pm 0.0 \mathrm{a}$ \\
\hline
\end{tabular}

Methanol extract was found to be more toxic when compared to the toxicities of the methanol and ethyl acetate extracts of olive leaf tested against the adults of the insect species (Tables 3-5, Figures S2-S4). In the current study, chromatographic study results showed that the methanol extract contains mainly oleuropein (1) besides a trisaccharide. The methanol extract was more toxic than oleuropein (1) against the adults of the tested insects (Tables 3-5, Figures S2-S4). This observation can be attributed to the toxic effects of other minor constituents in the methanol extract. Furthermore, chromatographic studies indicated that the ethyl acetate extracts consist of different amounts of triterpenoids, oleanolic acid (2), maslinic acid (3), erythrodiol (4) and uvaol (5). On the other hand, as can be seen from Tables 3-5 and Figures S2-S4, the insecticidal activities of the triterpenoids were found to be more toxic as compared with the ethyl acetate extract. Among these triterpenoids, maslinic acid (3) exhibited the highest toxicity against the three insects adults. Therefore, the low toxic effects of the ethyl acetate extract can be attributed to antagonistic interactions among these triterpenoids as well as other minor components. 
Table 4. Toxic effects of the extracts and the olive leaf metabolites against $T$. confusum.

\begin{tabular}{|c|c|c|c|c|c|}
\hline \multirow[b]{3}{*}{ Treatments } & \multirow[b]{3}{*}{$\begin{array}{c}\text { Conc. } \\
\text { (mg/Petri) }\end{array}$} & \multicolumn{4}{|c|}{ Mean mortality $(\%)^{\mathrm{a}}$} \\
\hline & & \multicolumn{4}{|c|}{ Exposure time (h) } \\
\hline & & 24 & 48 & 72 & 96 \\
\hline \multirow{3}{*}{$\mathrm{MeOH}$ extract } & 2.5 & $33.3 \pm 1.7 * \mathrm{~g}$ & $51.7 \pm 1.7 * \mathrm{f}$ & $65.0 \pm 2.9 * \mathrm{e}$ & $90.0 \pm 2.9 * f g$ \\
\hline & 5.0 & $40.0 \pm 0.0 * \mathrm{~h}$ & $53.3 \pm 1.7 * \mathrm{f}$ & $68.3 \pm 1.7 *_{\mathrm{ef}}$ & $90.0 \pm 2.9 * \mathrm{fg}$ \\
\hline & 7.5 & $43.3 \pm 1.7 * \mathrm{~h}$ & $61.7 \pm 1.7^{*} \mathrm{~g}$ & $76.7 \pm 1.7 * \mathrm{fg}$ & $91.7 \pm 1.7 * \mathrm{fgh}$ \\
\hline \multirow{3}{*}{ EtOAC extract } & 2.5 & $6.7 \pm 1.7 b c$ & $26.7 \pm 4.4 * \mathrm{~cd}$ & $43.3 \pm 4.4 * b$ & $66.7 \pm 1.7 * b c$ \\
\hline & 5.0 & $13.3 \pm 1.7 \mathrm{de}$ & $26.7 \pm 3.3 * \mathrm{~cd}$ & $43.3 \pm 4.4 * b$ & $73.3 \pm 4.4 * \mathrm{~cd}$ \\
\hline & 7.5 & $23.3 \pm 4.4 * \mathrm{f}$ & $41.7 \pm 3.3 * \mathrm{e}$ & $63.3 \pm 1.7 * \mathrm{de}$ & $80.0 \pm 5.0 * \mathrm{de}$ \\
\hline \multirow{3}{*}{ Oleuropein (1) } & 2.5 & $3.3 \pm 1.7 \mathrm{abc}$ & $21.7 \pm 1.7 * \mathrm{c}$ & $45.0 \pm 2.7 * \mathrm{~b}$ & $65.0 \pm 2.9 * \mathrm{~b}$ \\
\hline & 5.0 & $8.3 \pm 1.7 \mathrm{~cd}$ & $31.7 \pm 1.7 * \mathrm{~d}$ & $55.0 \pm 2.9 * \mathrm{~cd}$ & $80.0 \pm 2.9 * \mathrm{de}$ \\
\hline & 7.5 & $16.7 \pm 1.7 * \mathrm{e}$ & $33.3 \pm 1.7 * \mathrm{~d}$ & $55.0 \pm 3.7 * \mathrm{~cd}$ & $83.3 \pm 4.4 *$ ef \\
\hline \multirow{3}{*}{ Oleanolic acid (2) } & 2.5 & $1.7 \pm 1.7 \mathrm{ab}$ & $13.3 \pm 1.7 \mathrm{~b}$ & $48.3 \pm 1.7 * b c$ & $63.3 \pm 1.7 * b$ \\
\hline & 5.0 & $31.7 \pm 1.7 * \mathrm{~g}$ & $53.3 \pm 4.4 * f$ & $71.7 \pm 1.7 * \mathrm{efg}$ & $80.0 \pm 2.9 *$ de \\
\hline & 7.5 & $33.3 \pm 1.7 * \mathrm{~g}$ & $58.3 \pm 4.4 * \mathrm{fg}$ & $78.3 \pm 4.4 * \mathrm{~g}$ & $93.3 \pm 1.7 *^{\mathrm{gh}}$ \\
\hline \multirow{3}{*}{ Maslinic acid (3) } & 2.5 & $34.0 \pm 2.0 * \mathrm{~g}$ & $58.0 \pm 2.0 * \mathrm{fg}$ & $73.0 \pm 5.6 * \mathrm{fg}$ & $85.0 \pm 1.0 * \mathrm{efg}$ \\
\hline & 5.0 & $38.0 \pm 1.0 * \mathrm{~h}$ & $62.0 \pm 1.0 * \mathrm{~g}$ & $76.0 \pm 1.0 * \mathrm{fg}$ & $89.0 \pm 1.0 *$ fg \\
\hline & 7.5 & $44.0 \pm 1.0 * \mathrm{~h}$ & $67.0 \pm 2.0 * \mathrm{gh}$ & $85.7 \pm 6.7 * \mathrm{~g}$ & $97.0 \pm 2.0 * \mathrm{~h}$ \\
\hline \multirow{3}{*}{ Dichlorvos } & 2.5 & $91.7 \pm 1.7 *_{\mathrm{i}}$ & $100.0 \pm 0.0 * \mathrm{i}$ & $100.0 \pm 0.0 * \mathrm{~h}$ & $100.0 \pm 0.0 * \mathrm{~h}$ \\
\hline & 5.0 & $96.7 \pm 1.7 * \mathrm{ij}$ & $100.0 \pm 0.0 * \mathrm{i}$ & $100.0 \pm 0.0 * \mathrm{~h}$ & $100.0 \pm 0.0 * \mathrm{~h}$ \\
\hline & 7.5 & $100.0 \pm 0.0 * \mathrm{j}$ & $100.0 \pm 0.0 * \mathrm{i}$ & $100.0 \pm 0.0 * \mathrm{~h}$ & $100.0 \pm 0.0 * \mathrm{~h}$ \\
\hline $\begin{array}{l}\text { Control } \\
\text { (non-treated) }\end{array}$ & - & $0.0 \pm 0.0 \mathrm{a}$ & $0.0 \pm 0.0 \mathrm{a}$ & $0.0 \pm 0.0 \mathrm{a}$ & $0.0 \pm 0.0 \mathrm{a}$ \\
\hline
\end{tabular}

The LC value is dose that kills $50 \%$ of the insects when applied through the skin and mouth. It is generally given in $\mathrm{mg} / \mathrm{kg}$ and if the $\mathrm{LC}$ value of a substance is low, it is highly toxic [34]. The $\mathrm{LC}_{50}$ values (mg/Petri dish) in $72 \mathrm{~h}$ of the extracts and the olive leaf metabolites are compiled in Table 6. According to the $\mathrm{LC}_{50}$ values the lowest $\mathrm{LC}_{50}$ values $(0.25-4.54 \mathrm{mg} / \mathrm{Petri}$ dish) were calculated for $T$. confusum adults. $\mathrm{LC}_{50}$ values for $A$. obtectus and $S$. granarius were determined as $0.78-3.70 \mathrm{mg} /$ Petri dish and 2.92-16.73 mg/Petri dish, respectively. These results demonstrated that the extracts and the leaf metabolites are less effective against $S$. granarius adults. The LC values for commercial insecticide, dichlorvos were calculated in $24 \mathrm{~h}$ and these values were low $(0.11 \mathrm{mg} / \mathrm{Petri}$ dish for $S$. granarius, $0.87 \mathrm{mg} /$ Petri dish for T. confusum and $0.32 \mathrm{mg} /$ Petri dish for A. obtectus) as compared with those of the extracts and leaf metabolites (Table 6). The low $\mathrm{LC}_{50}$ values determined for dichlorvos postulated that the commercial insecticide was more effective against the adults of the insects in comparison to the leaf extracts and leaf metabolites of olive. Furthermore, the methanol extract $\left(\mathrm{LC}_{50}=0.25-3.58 \mathrm{mg} /\right.$ Petri dish) was more toxic than the ethyl acetate extract $\left(\mathrm{LC}_{50}=3.70\right.$ $16.73 \mathrm{mg} /$ Petri dish) against all of the tested pests with low $\mathrm{LC}_{50}$ values.

According to our literature survey, this is the first report on the insecticidal effects of the leaf extracts and leaf metabolites of the olive against $S$. granarius, $T$. confusum and A. obtectus pests. However, there have been some reports on insecticidal properties of the leaf extracts and its pure metabolites against various insects species [53-60]. Zia et al. (2011) tested the extract of olive leaves against chickpea beetle, Callosobruchus chinensis and they found it active against the beetle [57]. In the current study, oleanolic acid (2) was active against the $S$. granarius, $T$. confusum and A. obtectus (Tables 3-6 and Figures S2-S4). In accordance with our results, it has been reported that oleanolic acid 
(3) have toxic effect against Spodoptera frugiperda JE Smith, Spodoptera littoralis, Leptinotersa decemlineata, Myzus persicae and Bemisia tuberculata $[56,58,59]$. On the other hand, Pungitore et al. (2005) indicated that oleanolic acid (2) isolated from Junellia aspera exhibited less toxicity against Sitophilus oryzae (L.) [54]. According to our results, this compound showed weak toxic effect with $36.7-48.3 \%$ mortality after $72 \mathrm{~h}$ of treatment against $S$. granarius (Table 3). It has been also reported the high toxic effect of maslinic acid (3) against Sitophilus oryzae (L.) [54]. Likewise, maslinic acid (3) exhibited the highest insecticidal activity against $S$. granarius, $T$. confusum and A. obtectus with the lowest $\mathrm{LC}_{50}$ values of $0.66,0.61$ and $1.71 \mathrm{mg} /$ Petri dish, respectively (Table 6) among the tested substances.

Table 5. Toxic effects of the extracts and the olive leaf metabolites against A. obtectus.

\begin{tabular}{|c|c|c|c|c|c|}
\hline \multirow{3}{*}{$\begin{array}{l}\text { Treatments } \\
\text { s. }\end{array}$} & \multirow[b]{3}{*}{$\begin{array}{c}\text { Conc. } \\
\text { (mg/Petri) }\end{array}$} & \multicolumn{4}{|c|}{ Mean mortality $(\%)^{\mathrm{a}}$} \\
\hline & & \multicolumn{4}{|c|}{ Exposure time (h) } \\
\hline & & 24 & 48 & 72 & 96 \\
\hline \multirow{3}{*}{$\mathrm{MeOH}$ extract } & 2.5 & $18.3 \pm 1.7 * \mathrm{c}$ & $35.0 \pm 2.9 * \mathrm{bc}$ & $61.7 \pm 1.7 * \mathrm{de}$ & $76.7 \pm 1.7 * \mathrm{cde}$ \\
\hline & 5.0 & $26.7 \pm 1.7 * \mathrm{~d}$ & $43.3 \pm 1.7 * \mathrm{~cd}$ & $63.3 \pm 1.7 *_{\mathrm{e}}$ & $81.7 \pm 4.4 * \mathrm{efg}$ \\
\hline & 7.5 & $30.0 \pm 0.0 * \mathrm{~d}$ & $53.3 \pm 4.4 * \mathrm{e}$ & $71.7 \pm 1.7 * f$ & $91.7 \pm 1.7 * \mathrm{~h}$ \\
\hline \multirow{3}{*}{ EtOAC extract } & 2.5 & $18.3 \pm 3.3 * \mathrm{c}$ & $30.0 \pm 5.0 * \mathrm{~b}$ & $41.7 \pm 6.7 * b$ & $63.3 \pm 1.7 * b$ \\
\hline & 5.0 & $20.0 \pm 2.9 * \mathrm{c}$ & $33.3 \pm 6.0 * \mathrm{~b}$ & $53.3 \pm 3.3 * \mathrm{c}$ & $70.0 \pm 2.9 * \mathrm{c}$ \\
\hline & 7.5 & $31.7 \pm 1.7 * \mathrm{~d}$ & $46.7 \pm 3.3 * \mathrm{de}$ & $65.0 \pm 2.9 * \mathrm{ef}$ & $81.7 \pm 1.7 * \mathrm{efg}$ \\
\hline \multirow{3}{*}{ Oleuropein (1) } & 2.5 & $28.3 \pm 3.3 * \mathrm{~d}$ & $43.3 \pm 3.3 * \mathrm{~cd}$ & $66.7 \pm 1.7 *_{\mathrm{ef}}$ & $83.3 \pm 1.7 * \mathrm{efg}$ \\
\hline & 5.0 & $28.3 \pm 1.7 * \mathrm{~d}$ & $43.3 \pm 1.7 * \mathrm{~cd}$ & $68.3 \pm 1.7 * \mathrm{ef}$ & $86.7 \pm 1.7 * \mathrm{fgh}$ \\
\hline & 7.5 & $30.0 \pm 2.9 * \mathrm{~d}$ & $46.7 \pm 1.7 * \mathrm{de}$ & $68.3 \pm 1.7 * \mathrm{ef}$ & $88.3 \pm 3.3 * \mathrm{gh}$ \\
\hline \multirow{3}{*}{ Oleanolic acid (2) } & 2.5 & $11.7 \pm 1.7 \mathrm{~b}$ & $26.7 \pm 4.4 * \mathrm{~b}$ & $55.0 \pm 2.9 * \mathrm{~cd}$ & $73.3 \pm 1.7 * \mathrm{~cd}$ \\
\hline & 5.0 & $26.7 \pm 1.7 * \mathrm{~d}$ & $46.7 \pm 1.7 * \mathrm{de}$ & $61.7 \pm 1.7 * \mathrm{de}$ & $76.7 \pm 1.7 * \mathrm{cde}$ \\
\hline & 7.5 & $28.3 \pm 1.7 * \mathrm{~d}$ & $51.7 \pm 1.7 * \mathrm{de}$ & $68.3 \pm 1.7 * \mathrm{ef}$ & $80.0 \pm 2.9 * \mathrm{def}$ \\
\hline \multirow{3}{*}{ Maslinic acid (3) } & 2.5 & $26.0 \pm 1.0 * \mathrm{~d}$ & $40.0 \pm 2.0 * \mathrm{~cd}$ & $56.0 \pm 1.0 * \mathrm{~cd}$ & $70.0 \pm 1.0 * \mathrm{c}$ \\
\hline & 5.0 & $38.0 \pm 1.0 * \mathrm{e}$ & $54.0 \pm 0.0 * \mathrm{e}$ & $68.0 \pm 1.0 * \mathrm{ef}$ & $90.0 \pm 1.7 * \mathrm{~h}$ \\
\hline & 7.5 & $43.0 \pm 1.0 * \mathrm{ef}$ & $59.0 \pm 1.0 * \mathrm{ef}$ & $77.0 \pm 1.0 *$ fg & $97.0 \pm 1.0 * \mathrm{hi}$ \\
\hline \multirow{3}{*}{ Dichlorvos } & 2.5 & $91.7 \pm 3.3 * \mathrm{~g}$ & $100.0 \pm 0.0 * \mathrm{~g}$ & $100.0 \pm 0.0 * \mathrm{~h}$ & $100.0 \pm 0.0 *_{i}$ \\
\hline & 5.0 & $96.7 \pm 1.7 * \mathrm{~h}$ & $100.0 \pm 0.0 * \mathrm{~g}$ & $100.0 \pm 0.0 * \mathrm{~h}$ & $100.0 \pm 0.0 * \mathrm{i}$ \\
\hline & 7.5 & $98.3 \pm 1.7 * \mathrm{~h}$ & $100.0 \pm 0.0 * \mathrm{~g}$ & $100.0 \pm 0.0 * \mathrm{~h}$ & $100.0 \pm 0.0 *_{i}$ \\
\hline Kontrol & - & $0.0 \pm 0.0 \mathrm{a}$ & $0.0 \pm 0.0$ & $0.0 \pm 0.0 \mathrm{a}$ & $0.0 \pm 0.0 \mathrm{a}$ \\
\hline
\end{tabular}

${ }^{a}$ Mean \pm SE of three replicates, each set up with 20 adults. * Statistically different from control group according to LSD test. Values followed by different letters in the same column differ significantly at $\mathrm{p} \leq 0.05$ according to Duncan Multiple test. Conc.: Concentration

Table 6. $\mathrm{LC}_{50}$ values for the treatments ( $72 \mathrm{~h}$ after).

\begin{tabular}{lccc}
\hline \multicolumn{4}{c}{$\mathbf{L C}_{\mathbf{5 0}}$ (mg/Petri) } \\
\hline Treatment & S. granarius & T. confusum & A. obtectus \\
\hline MeOH extract & 3.58 & 0.25 & 0.78 \\
EtOAC extract & 16.73 & 4.54 & 3.70 \\
Oleuropein (1) & 7.69 & 3.82 & 0.34 \\
Oleanolic acid (2) & 8.39 & 2.57 & 1.73 \\
Maslinic acid (3) & 0.66 & 0.61 & 1.71 \\
Erythrodiol +uvaol (4+5) & 2.92 & - & - \\
Dichlorvos* & 0.11 & 0.87 & 0.32 \\
\hline
\end{tabular}

-: not determined.*: The values were determined $24 \mathrm{~h}$ after the treatment. 
In conclusion, $O$. europea emerged as a good source of traditional medicine for the treatment of various ailments of various countries of the world, in particular Mediterranean countries. The olive and its pure components have various pharmacological activities like antidiabetic, anticonvulsant, antioxidant, anti-inflammatory, immunomodulatory, analgesic, antimicrobial, cytotoxic and so on. According to our results, the levels of ALT, ALP, AST enzymes and glucose in the serums of fishes fed with pure olive metabolites were found to be high as compared with the control group. These results suggested that the compounds tested affect the liver metabolism of Nile tilapia. In particular, maslinic acid (2) considerably increased the ALT enzyme level that is a specific enzyme for the liver damage. Our results concluded that besides their therapeutic potentials of the olive leaves and its pure metabolites, their safety and adverse effects for human and other living health should also be thoroughly investigated. Compounds $\mathbf{1}, \mathbf{2}, \mathbf{3}$ and $\mathbf{4}+\mathbf{5}(2.5,5.0$ and $7.5 \mathrm{mg} /$ Petri dish concentrations) were also tested for contact toxic effects against three important stored pests, Sitophilus granarius (weevil), Tribolium confusum (confused flour beetle) and A. obtectus (bean weevil). The toxic effects of the metabolites were lower than those of the insecticide, dichlorvos (DDVP). DDVP caused complete mortality of the insects after 48 hours of treatments, the metabolites caused the mortality rates $16.7-63.3 \%, 13.3-67.0 \%$ and $26.7-59.0 \%$ of $S$. granarius, $T$. confusum and A. obtectus, respectively. According to $\mathrm{LC}_{50}$ values the metabolites, maslinic acid (3) was the most toxic compound with the lowest $\mathrm{LC}_{50}$ values $(0.66 \mathrm{mg} /$ Petri, $0.61 \mathrm{mg} /$ Petri and $1.71 \mathrm{mg} /$ Petri for $S$. granarius, $T$. confusum and A. obtectus, respectively). These results show that maslinic acid (3) as well as other substances can be used as natural insecticides against these pests. However, further studies are required to determine the cost, applicability and safety as potential herbicides.

\section{Acknowledgments}

The authors are grateful to the Kilis 7 Aralık University Research Foundation for financial support of this research (project no: BAP: 2014/01/MAP-05).

\section{Supporting Information}

Supporting Information accompanies this paper on http://www.acgpubs.org/RNP

\section{ORCID}

Ahmet K1sa:0000-0002-9851-6181

Mehmet Akyüz: 0000-0001-7971-8389

Hikmet Yeter Çoğun: 0000-0001-6559-4397

Şaban Kordali: 0000-0001-5669-5831

Ayşe Usanmaz Bozhüyük: 0000-0003-2450-6850

Binnur Tezel: 0000-0001-9379-6375

Ümran Şiltelioğlu: 0000-0001-7192-6589

Barış Anı1: 0000-0001-5382-0705

Ahmet Çakır: 0000-0003-1672-1438

\section{References}

[1] H.P.S. Makkar, G. Francis and K. Becker (2007). Bioactivity of phytochemicals in some lesser-known plants and their effects and potential applications in livestock and aquaculture production systems, Animal 1, 1371-1391.

[2] S.B.R. Castro, C.A.G. Leal, F.R. Freire, D.A. Carvalho, D.F. Oliveira and H.C.P. Figueiredo (2008). Antibacterial activity of plant extracts from Brazil against fish pathogenic bacteria, Braz. J. Microbiol. 39, 756-760. 
[3] A. Pachanawan, P. Phumkhachorn and P. Rattanachaikunsopon (2008). Potential of Psidium guajava supplemented fish diets in controlling Aeromonas hydrophila infection in tilapia (Oreochromis niloticus), J. Biosci. Bioeng. 106, 419-424.

[4] S.B. Chakraborty and C. Hancz (2011). Application of phytochemicals as immune stimulant, antipathogenic and antistress agents in finfish culture, Rev. Aquacult. 3, 103-119.

[5] S.J. Davies, A.A. Abdel-Warith and A. Gouveia (2011). Digestibility characteristics of selected feed ingredients for developing bespoke diets for Nile tilapia culture in Europe and North America, J. World Aquacult. Soc. 42, 388-398.

[6] R. Harikrishnan, C. Balasundaram and M.S. Heo (2011). Impact of plant products on innate and adaptive immune system of cultured finfish and shellfish, Aquaculture 317, 1-15.

[7] M.A. Haque, H. Nakakita, H. Ikenaga and N. Sota (2000). Development-inhibiting activity of some tropical plants against Sitophilus zeamais Motschulsky (Coleoptera : Curculionidae), J. Stored Prod. Res. 36, 281-287.

[8] A.K. Tripathi, V. Prajapati, K.K. Aggarwal and S. Kumar (2001). Toxicity, feeding deterrence, and effect of activity of 1,8-cineole from Artemisia annua on progeny production of Tribolium castanaeum (Coleoptera : Tenebrionidae), J. Econ. Entomol. 94, 979-983.

[9] E. Yildirim, A. Aslan, B. Emsen, A. Cakir and S. Ercisli (2012). Insecticidal effect of Usnea longissima (Parmeliaceae) extract against Sitophilus granarius (Coleoptera: Curculionidae), Int. J. Agric. Biol. 14, 303-306.

[10] I. Tunc and S. Sahinkaya (1998). Sensitivity of two greenhouse pests to vapours of essential oils, Entomol. Exp. Appl. 86, 183-187.

[11] S.M. Keita, C. Vincent, J.P. Schmit, S. Ramaswamy and A. Belangar (2000). Effect of various essential oils on Callosobruchus maculatus (F.) (Coleoptera : Bruchidae), J. Stored Prod. Res. 36, 355-364.

[12] T. Baytop (1999). Therapy with Medicinal Plants in Turkey (Past and Present). Istanbul University press, Istanbul.

[13] B. Amro, T. Aburjai and S. Ai-Khalil (2002). Antioxidative and radical scavenging effects of olive cake extract, Fitoterapia 73, 456-461.

[14] A. Bianco, M.A. Chiacchio, G. Grassi, D. Iannazzo, A. Piperno and R. Romeo (2006). Phenolic components of Olea europea: Isolation of new tyrosol and hydroxytyrosol derivatives, Food Chem. 95, $562-565$.

[15] N.S.A. Malik and J.M. Bradford (2006). Changes in oleuropein levels during differentiation and development of floral buds in 'Arbequina' olives, Sci. Hortic 110, 274-278.

[16] R. Japon-Lujan, J. Luque-Rodríguez and M. Luque de Castro (2006). Dynamic ultrasound assisted extraction of oleuropein and related biophenols from olive leaves, J. Chromatogr. A 1108, 76-82.

[17] J.G. Fernandez-Bolanos, O. Lopez, J. Fernandez-Bolanos and G. Rodriguez-Gutierrez (2008). Hydroxytyrosol and derivatives: isolation, synthesis, and biological properties, Curr. Org. Chem. 12, 442-463.

[18] M.A. Hashmi, H.S. Shah, A. Khan, U. Farooq, J. Iqbal, V.U. Ahmad and S. Perveen (2015). Anticancer and alkaline phosphatase inhibitory effects of compounds isolated from the leaves of Olea ferruginea Royle, Rec. Nat. Prod. 9, 164-168.

[19] O. Benavente-Garcia, J. Castillo, J. Lorente, J.A. Ortuno and D. Rio (2000). Antioxidant activity of phenolics extracted from Olea europaea L. leaves, Food Chem. 68, 457-462.

[20] A. Cumaoglu, N. Ari, M. Kartal and C. Karasu (2011). Polyphenolic extracts from Olea europea L. protect against cytokine-induced beta-cell damage through maintenance of redox homeostasis, Rejuv. Res. 14, 325-334.

[21] M. Katsiki, N. Chondrogianni, I. Chinou, A.J. Rivett and E.S. Gonos (2007). The olive constituent oleuropein exhibits proteasome stimulatory properties in vitro and confers life span extension of human embryonic fibroblasts, Rejuv. Res. 10, 157-172.

[22] E. Botsoglou, A. Govaris, D. Fletouris and S. Iliadis (2013). Olive leaves (Olea europea L.) and alphatocopheryl acetate as feed antioxidants for improving the oxidative stability of linolenic acid-enriched eggs, J. Anim. Physiol. An. N. 97, 740-753.

[23] S.O. Amoo, A.O. Aremu, M. Moyo and J. Van Staden (2012). Antioxidant and acetylcholinesteraseinhibitory properties of long-term stored medicinal plants, BMC Complem. Altern. M. 12, 87-92.

[24] O.K. Lee and B.Y. Lee (2010). Antioxidant and antimicrobial activities of individual and combined phenolics in Olea europaea leaf extract, Bioresource Technol. 101, 3751-3754.

[25] F. Bucher and R. Hofer (1990). Effect of domestic wastewater on serum enzyme activities of brown trout (Salmo trutta), Comp. Biochem. Phys. 97C, 385-391. 
[26] M.P. Cajaraville, M.J. Bebianno, J. Blasco, C. Porte, C. Sarasquete and A. Viarengo (2000). The use of biomarkers to assess the impact of pollution in coastal environments of the Iberian Peninsula: A practical approach, Sci. Total Environ. 247, 295-311.

[27] R.R. Hamed, N.M. Farid, S.H.E. Elowa and A.M. Abdalla (2003). Glutathione related enzyme levels of freshwater fish as bioindicators of pollution, The Environmentalist 23, 313-322.

[28] C.B. Cowey and M.J. Walton (1988). Intermediary metabolism in fish nutrition. Academic press, $2^{\text {nd }}$ edition, San Diego.

[29] J. Galina, G. Yin, L. Ardo and Z. Jeney (2009). The use of immunostimulating herbs in fish. An overview of research, Fish Physiol. Biochem. 35, 669-.676.

[30] H. Turker and A. Takemura (2011). Effects of environmental contaminants and natural substances on vitellogenesis in tilapia primary hepatocytes, Tur. J. Fish. Aquat. Sci. 11, 539-545.

[31] C.X. Lu, X.L. Luo, R.F. Luo, X. Chen, L.J. Xing, Z.G. Tang and H.M. Li (2013). Assessment of antibacterial properties and the active ingredient of plant extracts and its effect on the performance of crucian carp (Carassius auratusgibelio var. E'erqisi, Bloch), J. Sci. Food Agric. 93, 902-909.

[32] A. Freccia, S.M. de Negreiros Sousa, F. Meurer, A.J. Butzge, J.K. Mewes and R.A. Bombardelli (2014). Essential oils in the initial phase of broodstock diets of Nile tilapia, Rev. Bras. Zootecn. 43, 1-7.

[33] H. U. Bergmeyer and H. O. Beutler (1985). Ammonia, In: Methods of Enzymatic Analysis, ed: H. U. Bergmeyer, Verlag Chemie Weinheim, Deerfield Beach/ Florida, Basel, Vol. VIII, pp. 454-461.

[34] T. Aydin, A. Cakir, C. Kazaz, N. Bayrak, Y. Bayir and Y. Taskesenligil (2014). Insecticidal Metabolites from the Rhizomes of Veratrum album against adults of Colorado potato beetle, Leptinotarsa decemlineata, Chem. Biodivers. 11, 1192-1204.

[35] F.M. Moghaddam, M.M. Farimani, S. Salahvarzi and G. Amin (2006). Chemical constituents of dichloromethane extract of cultivated Satureja khuzistanica, Evid-Based Compl. Alt. Med. 4, 95-98.

[36] H. Saimaru, Y. Orihara, P. Tansakul, Y. H. Kang, M. Shibuya and Y. Ebizuka (2007). Production of triterpene acids by cell suspension cultures of Olea europaea, Chem. Pharm. Bull. 55, 784-788.

[37] R. Kotan, A. Cakir, H. Ozer, S. Kordali, R. Cakmakci, F. Dadasoglu, N. Dikbas, T. Aydin and C. Kazaz (2014). Antibacterial effects of Origanum onites against phytopathogenic bacteria: possible use of the extracts from protection of disease caused by some phytopathogenic bacteria, Sci. Hortic. 172, 210-220.

[38] I. Khlif, K. Hamden, M. Damak and N. Allouche (2012). A new triterpene from Olea europea stem with antidiabetic activity, Chem. Nat. Compd. 48, 799-802.

[39] C.F.Zhang, X.F. Liu, Y.Y. Zhao and M. Zhang (2016). Evaluation of anti-inflammatory and immunosuppressive properties of Cynanchum ascyrifolium Matsum. and its active secondary metabolites, Rec. Nat. Prod. 10, 526-529.

[40] J. Peragon (2013). Time course of pentacyclic triterpenoids from fruits and leaves of olive tree (Olea europea L.) cv. Picual and cv. Cornezuelo during ripening, J. Agric. Food Chem. 61, 6671-6678.

[41] F.J. Reyes-Zurita, E.E. Rufino-Palomares, J.A. Lupianez and M. Cascante (2009). Maslinic acid, a natural triterpene from Olea europea L., induces apoptosis in HT29 human colon-cancer cells via the mitochondrial apoptotic pathway, Cancer Lett. 273, 44-54.

[42] L.I. Somova, F.O. Shodeb, P. Ramnanana and A. Nadara (2003). Antihypertensive, antiatherosclerotic and antioxidant activity of triterpenoids isolated from Olea europaea, subspecies Africana leaves, $J$. Ethnopharmacol, 84, 299-305.

[43] F.J., Reyes, J.J. Centelles, J.A. Lupianez and M. Cascante (2006). (2 alpha,3 beta)-2,3-Dihydroxyolean12-en-28-oic acid, a new natural triterpene from Olea europea, induces caspase dependent apoptosis selectively in colon adenocarcinoma cells, FEBS Lett. 580, 6302-6310.

[44] J. Nemcsok, L. Orban, B. Asztalos and E. Vig, B (1987). Accumulation of pesticides in the organs of carp (Cyprinus carpio L.) at $4{ }^{\circ} \mathrm{C}$ and $20^{\circ} \mathrm{C}$, Environ. Contam. Tox. 39, 370-378.

[45] J. Nemcsok and G.M. Hughes (1988). The effect of copper sulphate on some biochemical parameters of rainbow trout, Environm. Pollut. 49, 77-85.

[46] S. Kalender, A. Ogutcu, M. Uzunhisarciki, F. Acikgoz, D. Durak, Y. Ulusoy and Y. Kalender (2005). Diazinon-induced hepatotoxicity and protective effect of vitamin E on some biochemical indices and ultrastructural changes, Toxicology 211, 197-206.

[47] N.C. Jain (1986). Schalm's Veterinary Hematology', $4^{\text {th }}$ Edition, Lea and Febiger, Philadelphia, PA.

[48] R.J. Duncan, K.W. Prasse and E.A. Mahaffey (1994). Veterinary Laboratory Medicine Clinical Pathology. $3^{\text {rd }}$ Edition, Iowa State Press, Ames, IA. 
[49] L. Kalaycıoğlu, B. Serpak, M. Nizamlioglu, N. Baspinar and A.M. Tiftik (2000). Biyokimya. $2^{\text {nd }}$ Edition, Nobel Yayın Dağıtım Press, Ankara.

[50] P.C. Champe, R.A. Harvey and D.R. Ferrier (2007). Lippincott's Illustrated Reviews; Biochemistrys. Nobel Tip Kitabevleri Press., 3rd edition, Istanbul.

[51] F.B. Eddy (1982). Osmotic and ionic regulation in captive fish with particular reference to salmonids, Comp. Biochem. Phys. B 73, 125-141.

[52] D.G. McDonald and C.M. Wood, (1993). Fish ecophysiology, fish and fisheries series, In: Branchial Mechanism of Acclimation to Metals in Freshwater Fish, Eds: J.C. Rankin, F.B. Jensen, Champman and Hal, London, Vol. 19, pp. 297-321.

[53] A.C. Leite, F.C. Bueno, C.G. Oliveira, J.B. Fernandes, P.C. Vieria, M.F.G.F. da Silva, O.C. Bueno, F.C. Pagnocca, M.J.A. Hebling and M. Bacci (2005). Limonoids from Cipadessa fruticosa and Cedrela fissilis and their insecticidal activity, J. Brazil. Chem. Soc. 16, 1391-1395.

[54] C.R. Pungitore, M. Garcia, J.C. Gianello, M.E. Sosa and C.E. Tonn (2005). Insecticidal and antifeedant effects of Junellia aspera (Verbenaceae) triterpenes and derivatives on Sitophilus oryzae (Coleoptera: Curculionidae), J. Stored Prod. Res. 41, 433-443.

[55] D.A.C. Biggs, R.B.P. Porter, W.F. Reynolds and L.A.D. Williams (2008). New hyptadienic acid derivative from Hyptis verticillata (Jacq.) with insecticidal activity, Nat. Prod. Commun. 11, 17591762 .

[56] A. Gonzalez-Coloma, C. Lopez-Balboa, O. Santana, M. Reina and B.M. Fraga (2011). Triterpene-based plant defenses, Phytochem. 10, 245-260.

[57] A. Zia, M. Aslam, F. Naz and M. Illyas (2011). Bio-efficacy of some plant extracts against chickpea beetle, Callosobruchus chinensis Linnaeus (Coleoptera: Bruchidae) attacking chickpea, Pak. J. Zool. 43, 733-737.

[58] R. Maties, A.R. Roel, N.N. Andrade, E.E.J.D. Schleder, D.S. Yasunaka and C.A.L. Cardoso (2013). Control of silverleaf whitefly in cassava grown in the greenhouse treated with Anacardium humile (Anacardiaceae) extract, Biosci. J. 29, 1815-1822.

[59] J.R. Salazar, P. Torres, B. Serrato, M. Dominguez, J. Alarcon and C.L. Cespedes (2015). Insect growth regulator (IGR) effects of Eucalyptus citriodora Hook (Myrtaceae), Bol. Latioam. Caribe 14, 403-422.

[60] M.A. Hashmi, A. Khan, M. Hanif, U. Farooq and S. Perveen (2015). Traditional uses, phytochemistry, and pharmacology of Olea europaea (olive), Evid-Based Compl. Alt. Med. article ID 541591, 29 pages.

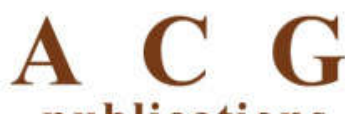

publications

(C) 2018 ACG Publications 